\title{
Gonadotropin-Releasing Hormone Neurones Innervate Kisspeptin Neurones in the Female Mouse Brain
}

\author{
Imre Kallóa, b Barbara Vida ${ }^{a}$ Zsuzsanna Bardóczi ${ }^{a}$ Anett Szilvásy-Szabóa \\ Fruzsina Rabi $^{a}$ Tamás Molnár $^{a, b}$ Imre Farkas $^{a}$ Alain Caraty ${ }^{d}$ \\ Jens Mikkelsen ${ }^{\mathrm{e}}$ Clive W. Coen ${ }^{\mathrm{c}}$ Erik Hrabovszky ${ }^{\mathrm{a}}$ Zsolt Liposits ${ }^{\mathrm{a}} \mathrm{b}$ \\ a Laboratory of Endocrine Neurobiology, Institute of Experimental Medicine, Hungarian Academy of \\ Sciences, and bepartment of Neuroscience, Faculty of Information Technology, Pázmány Péter Catholic University, \\ Budapest, Hungary; ' Reproductive Neurobiology, Division of Women's Health, School of Medicine, King's College, \\ London, UK; ${ }^{d}$ INRA, Physiologie de la reproduction et des comportements, Nouzilly, France; ${ }^{\text {eDepartment of }}$ \\ Translational Neurobiology, NeuroSearch A/S, Ballerup, Denmark
}

\section{Key Words}

Rostral periventricular area of the third ventricle .

Anteroventral periventricular nucleus - Arcuate nucleus . Asymmetric synapses · Reciprocal innervation - Oestrogen

\begin{abstract}
Kisspeptin (KP) neurones in the rostral periventricular area of the third ventricle (RP3V) and arcuate nucleus (Arc) are important elements in the neuronal circuitry regulating gonadotropin-releasing hormone $(\mathrm{GnRH})$ secretion. $\mathrm{KP}$ and cosynthesised neuropeptides/neurotransmitters act directly on GnRH perikarya and processes. GnRH neurones not only form the final output pathway regulating the reproductive functions of the anterior pituitary gland, but also provide neuronal input to sites within the hypothalamus. The current double-label immunohistochemical studies investigated whether GnRH-immunoreactive (IR) projections to the RP3V and/or Arc establish morphological connections with KP-IR neurones at these sites. To optimise visualisation of KP immunoreactivity in, respectively, the RP3V and Arc, ovariectomised (OVX) oestrogen-treated and OVX oil-treated female mice were studied. Confocal laser microscopic analysis of im-
\end{abstract}

munofluorescent specimens revealed GnRH-IR axon varicosities in apposition to approximately $25 \%$ of the KP-IR neurones in the RP3V and 50\% of the KP-IR neurones in the Arc. At the ultrastructural level, GnRH-IR neurones were seen to establish asymmetric synaptic contacts, which usually reflect excitatory neurotransmission, with KP-IR neurones in both the RP3V and Arc. Together with previous data, these findings indicate reciprocal connectivity between both of the KP cell populations and the GnRH neuronal system. The functional significance of the GnRH-IR input to the two separate KP cell populations requires electrophysiological investigation.

(c) 2013 S. Karger AG, Basel

\section{Introduction}

Gonadotropin-releasing hormone (GnRH)-producing neurones form the final common pathway for the hypothalamic neuronal circuitry that regulates gonadal functions. GnRH not only drives the anterior pituitary gland functions that govern ovarian steroidogenesis, follicular maturation and ovulation, but also acts as a neu-

\section{KARGER}

E-Mail karger@karger.com

www.karger.com/nen
(C) 2013 S. Karger AG, Basel

0028-3835/13/0984-0281\$38.00/0
Imre Kalló

Laboratory of Endocrine Neurobiology, Institute of Experimental Medicine Hungarian Academy of Sciences

PO Box 67, HU-1450 Budapest (Hungary)

E-Mail kallo@koki.hu 
romodulator within the brain $[1,2]$. Accordingly, there is evidence that central administration of $\mathrm{GnRH}$ can inhibit the reproductive axis in sheep $[3,4]$ and rats $[5,6]$.

Previous immunohistochemical studies have identified putative sites for central actions of GnRH. Thus, GnRH-immunoreactive (IR) axon projections are detected in the preoptic area and anteroventral periventricular nucleus (AVPV) $[1,7,8]$; the latter plays an essential role in mediating the positive feedback effects of oestrogen that culminate in the surge release of $\mathrm{GnRH}$ [9]. GnRHIR processes are also present in the mediobasal hypothalamus (MBH) [1,7], including the arcuate nucleus (Arc), a site that is implicated in the pulsatile regulation of GnRH release [9] and in the negative feedback effect of oestrogen on GnRH secretion [10].

Oestrogen receptor (ER) $\alpha$-expressing neurones mediate the positive [11] and negative [12] feedback effects of oestrogen onto the GnRH neurones. Given that the latter express ER $\beta$ rather than ER $\alpha 13]$, the neurotransmitter phenotype and anatomical location of the ER $\alpha$-expressing neurones that communicate oestrogen-induced signals to GnRH neurones have been the subject of intense investigation over the past three decades $[14,15]$. The hypothalamic kisspeptin (KP) system appears to be involved in both the pulsatile [16] and surge [17-21] modes of $\mathrm{GnRH}$ release. It consists of two distinct cell populations located within the rostral periventricular area of the third ventricle (RP3V), including the AVPV and periventricular preoptic nucleus, and the Arc $[22,23]$. Both of these KP cell populations express ER $\alpha[24,25]$ and send projections that innervate GnRH-IR neurones [26, 27]; thus, they have the capacity to convey critically important oestrogen-dependent signals to GnRH neurones.

Given the evidence that KP neurones innervate $\mathrm{GnRH}$ neurones and that GnRH has actions within the hypothalamus that can influence the reproductive axis, we have used confocal and electron microscopic immunohistochemical approaches to test the hypothesis that $\mathrm{GnRH}$ neurones in female mice innervate KP-IR neurones in the RP3V and/or Arc.

\section{Materials and Methods}

\section{Animals}

Adult female CD1 mice (2-3 months old, 25-30 g b.w.; Charles River, Hungary) were housed under controlled lighting (12:12 h light-dark cycle; lights on at 07:00 h, Zeitgeber time (ZT)0) and temperature $\left(22 \pm 2^{\circ} \mathrm{C}\right)$, with access to food and water ad libitum. All studies were carried out with permission from the Animal Welfare Committee of the Institute of Experimental Medicine (No.
2285/003) and in accordance with legal requirements of the European Community (Decree 86/609/EEC). Surgery was performed on animals under deep anaesthesia induced by an intraperitoneally injected cocktail of ketamine ( $25 \mathrm{mg} / \mathrm{kg}$ b.w.), xylavet $(5 \mathrm{mg} /$ $\mathrm{kg}$ b.w.) and pipolphen ( $2.5 \mathrm{mg} / \mathrm{kg}$ b.w.) in saline.

\section{Tissue Preparation for Confocal Microscopy}

The animals were ovariectomised (OVX, day 0 ) and 7 days later (day 7) implanted subcutaneously with a capsule (ID $1.57 \mathrm{~mm}$, OD $3.18 \mathrm{~mm})$ containing either $17 \beta$-oestradiol $(0.625 \mu \mathrm{g}$ in $20 \mu \mathrm{l}$ sunflower oil; $\mathrm{OVX}+\mathrm{E}_{2}$ ) or vehicle (OVX+Oil) [28]. Three days after implantation (day 10), the mice were colchicine-treated intracerebroventricularly ( $40 \mu \mathrm{g}$ in $4 \mu \mathrm{l} 0.9 \%$ saline) and $24 \mathrm{~h}$ later (day 11) they were sacrificed at either ZT4-5 ( $\mathrm{n}=5$ for OVX $+\mathrm{E}_{2}$ and for OVX+Oil) or ZT11-12 ( $\mathrm{n}=5$ for OVX+E $; \mathrm{n}=7$ for OVX+Oil), whether or not they had been treated with oestrogen; these times include, respectively, the negative and positive feedback phases of oestrogen's effects on LH release. The animals were perfused transcardially with phosphate-buffered saline (PBS; $0.1 \mathrm{M}$ ) containing $4 \%$ paraformaldehyde (PFA). The brains were post-fixed in $2 \% \mathrm{PFA} / \mathrm{PBS}$ solution for $24 \mathrm{~h}$ at $4^{\circ} \mathrm{C}$, cryoprotected overnight in $25 \%$ sucrose and $25-\mu \mathrm{m}$ thick coronal sections were cut on a freezing microtome. The sections were divided into three sequential pools and stored in antifreeze solution (30\% ethylene glycol; $25 \%$ glycerol; $0.05 \mathrm{M}$ phosphate buffer; $\mathrm{pH} 7.4$ ) at $-20^{\circ} \mathrm{C}$ until use. After the endogenous peroxidase activity had been quenched with $0.5 \%$ hydrogen peroxide $(10 \mathrm{~min})$, sections were permeabilised with $0.5 \%$ Triton X-100 (23,472-9, Sigma, 20 min). Finally, $2 \%$ normal horse serum was applied $(20 \mathrm{~min})$ to reduce non-specific antibody binding. Subsequent treatments and interim rinses in PBS $(3 \times 5 \mathrm{~min})$ were carried out at room temperature, except for incubation in the primary antibody or fluorochrome conjugate, which took place at $4^{\circ} \mathrm{C}$.

\section{Tissue Preparation for Electron Microscopy}

In order to investigate putative GnRH-KP appositions in the RP3V and Arc at the electron microscopic level, pre-embedding, double-label immunohistochemistry was carried out. For tissue preservation of oestrogen or oil-treated OVX animals $(\mathrm{n}=5$ each), which also received colchicine intracerebroventricularly, a mixture of $2 \%$ PFA and $4 \%$ acrolein was used. $30-\mu \mathrm{m}$ thick coronal sections were cut with a vibratome and treated with $1 \%$ sodium borohydride (30 $\mathrm{min}), 0.5 \% \mathrm{H}_{2} \mathrm{O}_{2}(15 \mathrm{~min})$ and permeabilised with three freeze-thaw cycles, as described previously [29].

\section{Double Immunofluorescence for $G n R H$ and KP}

Immunoreactivity

Sections from the $\mathrm{RP} 3 \mathrm{~V}$ region of the $\mathrm{OVX}+\mathrm{E}_{2}$ animals and the Arc region of the OVX+Oil animals were incubated $(72 \mathrm{~h})$ in a cocktail of the guinea pig anti-GnRH (\#1018, Hrabovszky, $1: 10,000)$ [30] and rabbit anti-KP (\#566, Caraty, 1:10,000) [25] primary antibodies. GnRH immunoreactivity was visualised with CY3-conjugated donkey anti-guinea pig IgG (\#706-165-148, Jackson ImmunoResearch Laboratories, 1:1,000, $12 \mathrm{~h}$ ). To visualise the KP-IR structures, the sections were incubated sequentially in biotinylated donkey anti-rabbit (\#711-065-152, Jackson ImmunoResearch Laboratories, 1:1,000, 2 h), Vectastain ABC Elite solution (PK-6100, Vector Laboratories, 1:1,000, $1 \mathrm{~h}$ ), biotinylated tyramide with $\mathrm{H}_{2} \mathrm{O}_{2}$ (1:1,000 and $0.006 \%$, respectively; $\left.0.5 \mathrm{~h}\right)$ and, finally, Alexa 488-streptavidin (S-11227, Molecular Probes, 1:500, 12 h). 
Confocal Laser Analysis and 3-D Reconstruction of GnRH-IR Afferents to KP-IR Neurones in the RP3V and Arc

The double-labelled sections were analysed using a Radiance 2100 confocal microscope (Bio-Rad Laboratories, Hemel Hempstead, UK). Three sections were selected per brain from the RP3V (at bregma +0.38 to $+0.26,+0.26$ to +0.02 and +0.02 to $-0.1 \mathrm{~mm}$ ) and the Arc (at bregma -1.46 to $-1.7,-1.94$ to -2.06 and -2.3 to $-2.54 \mathrm{~mm})$ [31]. Multiple stacks of optical slices $(512 \times 512$ pixels, $\mathrm{z}$-steps $0.6 \mu \mathrm{m}$ ) were obtained by scanning all of the KP-IR neurones unilaterally in each of the selected coronal sections using a $60 \times$ oil immersion objective. The Alexa 488 and CY3 fluorochromes were detected with laser lines 488 and $543 \mathrm{~nm}$, using dichroic/emission filters 560/500-540 nm and 650/560-610 nm, respectively. The separately recorded green and red channels were merged and displayed with the Laser Vox software (Bio$\mathrm{Rad}$ ) running on an IBM-compatible personal computer. The number of KP-IR neurones contacted by GnRH-IR processes and the incidence of GnRH-IR appositions on individual KP-IR neurones were quantified. Appositions were identified if no gap was visible between the juxtaposed profiles in at least one optical slice. Differences were assessed by ANOVA with a priori planned contrasts (IBM SPSS, Version 20) testing the hypotheses that the dependent variable differs (1) within each region across the time points and (2) between the regions at the same time point. Data are presented as mean \pm SEM. Statistical significance was set at $\mathrm{p}<0.05$. The images acquired with the confocal laser microscope were further investigated using three-dimensional (3-D) analyses. The stack of optical slices was loaded into the visualisation software ImageSurfer 1.20 and the two channels containing images of consecutive optical slices were rendered in three dimensions with the Isosurface visualisation application. The isovalue was set individually for each image to minimise any noise, while maintaining the proper cellular boundaries. The isosurfaces generated from the two channels in the same optical volume were visualised to check for cell-to-cell contacts. This enabled verification of the findings from the two dimensional confocal image analyses.

\section{Electron Microscopy to Investigate Synaptic Relations of}

GnRH-IR Varicosities and KP-IR Neurones

Sections from the RP3V and Arc of, respectively, $\mathrm{OVX}+\mathrm{E}_{2}$ and $\mathrm{OVX}+\mathrm{Oil}$ mice were double labelled for $\mathrm{GnRH}$ and $\mathrm{KP}$ immunoreactivity. They were incubated (2 days) concurrently in the primary antibodies (guinea pig anti-GnRH, \#1018, Hrabovszky, $1: 600,000$; rabbit anti-KP, \#566, Caraty, $1: 100,000$ ). This was followed by visualisation of the GnRH-IR structures by incubating the sections sequentially in biotinylated donkey anti-guinea pig IgG (\#706-065-148, Jackson ImmunoResearch Laboratories, 1:1,000, 1 day) and Vectastain ABC Elite solution (1:1,000, $1.5 \mathrm{~h})$. The peroxidase reaction was carried out in the presence of $\mathrm{H}_{2} \mathrm{O}_{2}$ and nickel-diaminobenzidine (NiDAB), and post-intensified with silver-gold (SGI-NiDAB) [32]. After this reaction, the KP-IR structures were detected by incubating sections sequentially in biotinylated donkey anti-rabbit IgG (\#711-065-152, Jackson ImmunoResearch Laboratories, 1:1,000, 1 day) and Vectastain ABC Elite solution $(1: 1,000 ; 1.5 \mathrm{~h})$ and the peroxidase reaction was carried out in the presence of $\mathrm{H}_{2} \mathrm{O}_{2}$ and DAB alone. The double-labelled sections were then treated with $1 \%$ osmium tetroxide $(1 \mathrm{~h})$ and $2 \%$ uranyl acetate (in 70\% ethanol; $40 \mathrm{~min}$ ), dehydrated in an ascending series of ethanol and propylene oxide, and flat-embedded in
TAAB 812 medium epoxy resin between glass microscope slides pre-coated with a liquid release agent (\#70880; Electron Microscopy Sciences, Fort Washington, Pa., USA). The resin was allowed to polymerise at $56^{\circ} \mathrm{C}$ for 2 days. The flat-embedded sections were initially investigated by light microscopy at $60 \times$ magnification; areas exhibiting appositions of GnRH-IR processes on the somatodendritic region of KP-IR neurones within the RP3V and Arc were selected for further processing. Semithin $(1 \mu \mathrm{m})$ and ultrathin $(50-$ $60 \mathrm{~nm}$ ) sections were cut with a Leica ultracut UCT ultramicrotome (Leica Microsystems, Vienna, Austria). The ultrathin sections were collected in ribbons onto Formvar-coated single-slot grids, contrasted with $2 \%$ lead citrate and examined with a Jeol100C transmission electron microscope.

\section{Immunohistochemical Controls}

The specificities of the GnRH and KP primary antisera have been reported previously $[25,33]$. Immunohistochemical controls included the use of increasing dilutions of the primary antisera, which resulted in a commensurate decrease and eventual disappearance of the immunostaining; omission of the primary antibodies or their preabsorption with corresponding peptide antigens resulted in complete loss of the immunostaining. The secondary antibodies employed here were designed for multiple labelling and pre-absorbed by the manufacturer with immunoglobulins from several species, including the one in which the other primary antibody had been raised.

\section{Results}

Confocal microscopic analysis revealed appositions between GnRH-IR processes and KP neurones. Electron microscopy identified synapses between GnRH-IR terminals and KP-IR neurones.

\section{GnRH-IR Processes Form Appositions on KP-IR \\ Perikarya and Dendrites in the RP3V and Arc}

In keeping with the established distribution of $\mathrm{GnRH}$ in rats and mice, GnRH-IR cell bodies were found in the septo-preoptico-hypothalamic continuum and their processes were seen to course through and form varicosities in the RP3V (fig. 1a-c) and MBH (fig. 1d-f), two regions which contain KP-IR neurones. The expression of $\mathrm{KP}$ is differentially regulated by oestrogen in these two regions, being up-regulated in the RP3V and downregulated in the Arc [24]; therefore, animal models with either high $\left(\mathrm{OVX}+\mathrm{E}_{2}\right)$ or low $(\mathrm{OVX}+\mathrm{Oil})$ oestrogen levels were prepared to increase the detectability of KP in the respective regions. In addition, colchicine-treatment was employed to maximise peptide immunoreactivity in the somatodendritic region of KP neurones. Studies using double-label immunofluorescence identified KP-IR neurones in the RP3V within a plexus of GnRH-IR processes; some of these processes run close to the ependy- 
Fig. 1. Representative coronal images of the mouse brain showing immunohistochemical double labelling for GnRH (red) and KP (green) at three rostro-caudal levels of the RP3V (a-c) and of the MBH (d-f). KP-IR cell bodies in the AVPV, periventricular $(\mathrm{Pe})$ and Arc nuclei are intermingled within a plexus of varicose $\mathrm{GnRH}$ processes. Some of these processes run close to the ependymal layer of the third ventricle (3V) in the AVPV and PE (a-c), others arch away from the $3 \mathrm{~V}(\mathbf{d}, \mathbf{e})$ or form a dense ventral bundle coursing towards the median eminence (d-f). Scale bars: $50 \mu \mathrm{m}(\mathbf{a}-\mathbf{f})$.
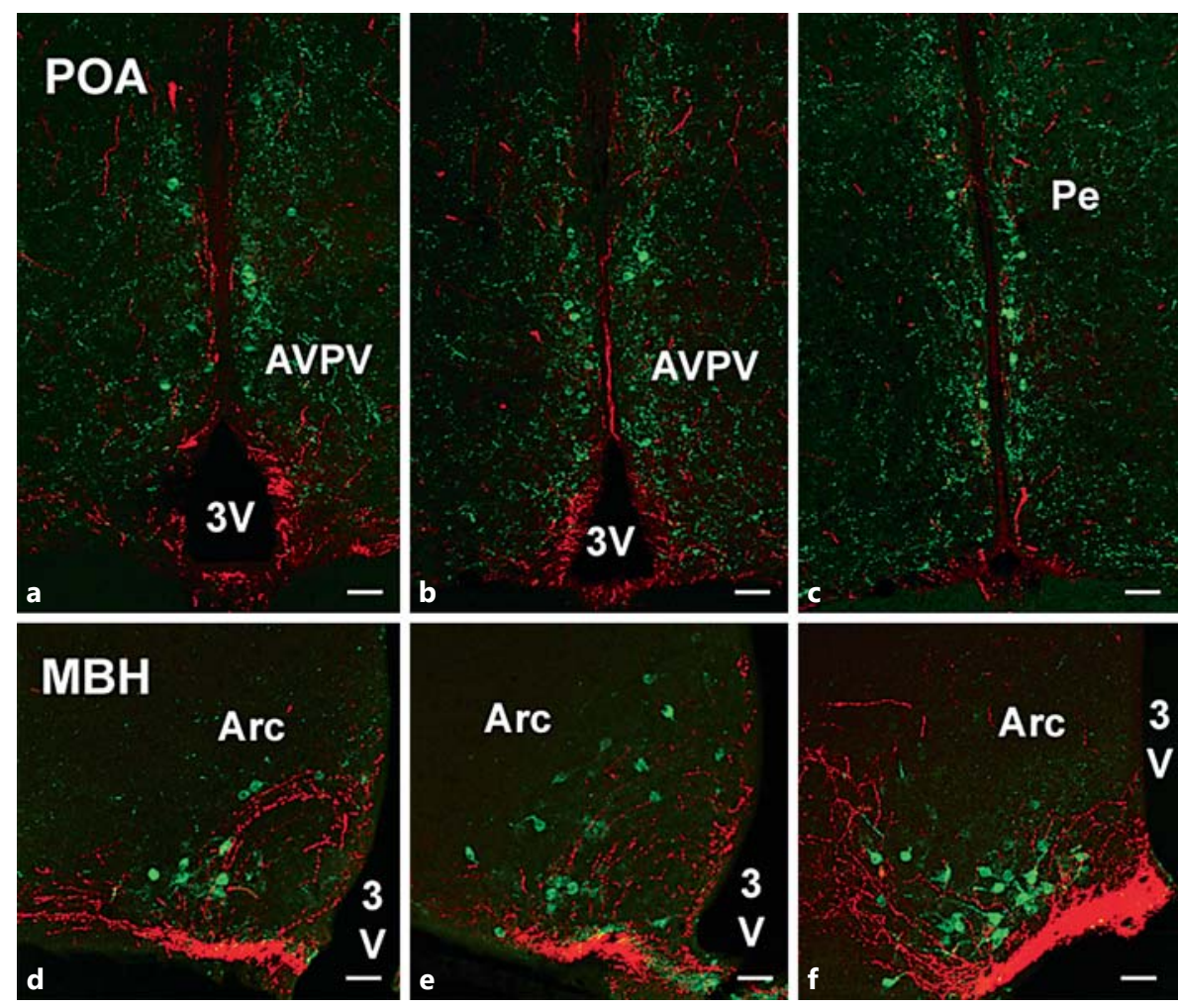

Table 1. Percentage $( \pm$ SEM) of KP-IR neurones found with apposed GnRH-IR axon varicosities and the mean $( \pm$ SEM) number of such appositions detected on those KP-IR neurones in the RP3V and Arc

\begin{tabular}{|c|c|c|c|c|}
\hline & \multicolumn{2}{|l|}{ RP3V } & \multicolumn{2}{|l|}{ Arc } \\
\hline & $\begin{array}{l}\text { at ZT4-5 } \\
(\mathrm{n}=5)\end{array}$ & $\begin{array}{l}\text { at ZT11-12 } \\
(\mathrm{n}=7)\end{array}$ & $\begin{array}{l}\text { at ZT4-5 } \\
(\mathrm{n}=5)\end{array}$ & $\begin{array}{l}\text { at ZT11-12 } \\
(\mathrm{n}=5)\end{array}$ \\
\hline Percentage of KP-IR neurones with GnRH-IR appositions & $23.79 \pm 6.93$ & $28.19 \pm 4.41$ & $45.99 \pm 3.02^{*}$ & $55.13 \pm 4.62^{*}$ \\
\hline Number of GnRH-IR appositions per innervated KP neurones & $2.57 \pm 0.47$ & $2.97 \pm 0.26$ & $3.31 \pm 0.31$ & $3.57 \pm 0.31$ \\
\hline
\end{tabular}

The animals were sacrificed at ZT4-5 or at ZT11-12. Neither parameter in the RP3V or Arc shows a significant difference between animals sacrificed at the two ZTs. * Significantly greater $(\mathrm{p}<0.003)$ percentage of KP-IR neurones with GnRH-IR appositions in the Arc than in the RP3V at the corresponding time.

mal layer of the third ventricle near the most medial KPIR neurones (fig. 1a-c, 3a). In the Arc, KP-IR neurones were found in the vicinity of GnRH-IR processes, which were either arching away from the third ventricle (fig. 1d, e) or forming a dense ventral bundle coursing towards the median eminence (fig. 1d-f). Confocal microscopic analysis and 3-D reconstruction of the labelled cellular profiles identified GnRH-IR axon varicosities juxtaposed to KP-IR perikarya or dendrites in both the RP3V (fig. 2a, b) and Arc (fig. 2c, d). In the animal models used for quantifying the innervation in the RP3V (colchicinetreated $\mathrm{OVX}+\mathrm{E}_{2}$ mice) and in the Arc (colchicine-treated OVX+Oil mice), GnRH-IR axon varicosities were seen to contact approximately $25 \%$ of the RP3V KP-IR neurones [ $23.79 \pm 6.93 \%$ at ZT4 $-5(\mathrm{n}=5)$ and $28.19 \pm$ $4.41 \%$ at ZT $11-12(\mathrm{n}=7)]$ and approximately $50 \%$ of the Arc KP-IR neurones [ $45.99 \pm 3.02 \%$ at ZT4-5 $(n=5)$ and $55.13 \pm 4.62 \%$ at ZT11-12 $(\mathrm{n}=5)]$; the percentage 
Fig. 2. High-power photomicrographs (a, $\mathbf{c}=$ optical slices; $\mathbf{b}, \mathbf{d}=$ projected image of reconstructed $\mathrm{Z}$ stacks) of sections immunohistochemically double labelled for GnRH (red) and KP (green). GnRH-IR varicose processes (red) are in apposition to KP-IR cell bodies (arrowheads) or processes (arrows) in the AVPV (a, b) and Arc (c, d). Scale bars: $20 \mu \mathrm{m}(\mathbf{a}, \mathbf{c}), 10 \mu \mathrm{m}(\mathbf{b}, \mathbf{d})$.
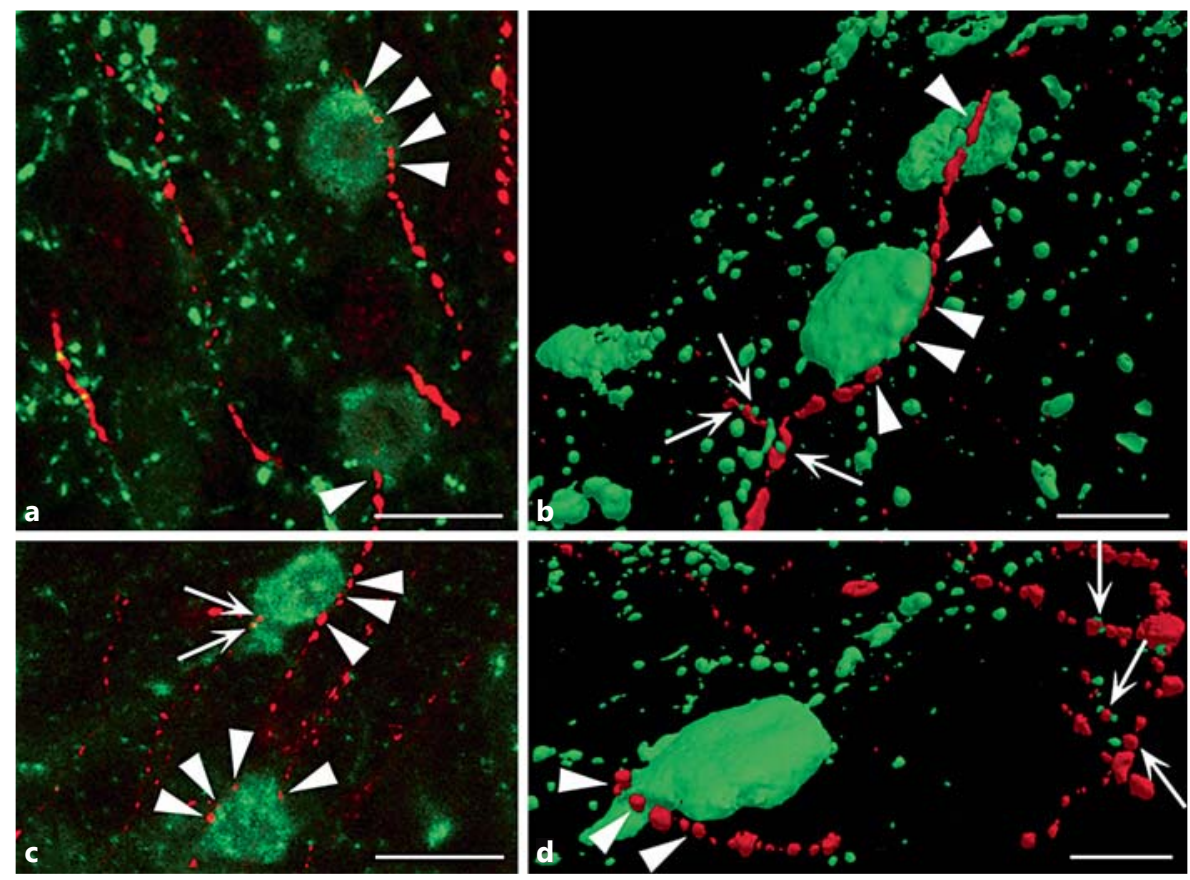

was unaffected by the ZT (table 1 ). At each of the investigated times there was a significantly greater $(\mathrm{p}<0.003)$ percentage of KP-IR neurones with GnRH-IR appositions in the Arc than in the RP3V. At both sites, the mean number of GnRH-IR appositions on their target KP-IR neurones was approximately 3 ; this number was unaffected by the ZT (table 1).

\section{GnRH-IR Axon Terminals Establish Asymmetric}

Synapses on KP-IR Neurones in the RP3V and Arc

The immunofluorescent identification of appositions between GnRH-IR varicosities and KP-IR neurones in the RP3V and ARC prompted an initial investigation for classical synapses at the ultrastructural level. Pre-embedding immunohistochemical double labelling (fig. 3a), employing two distinct electron dense markers, enabled the electron microscopic identification of pre- and postsynaptic elements. This made it possible to select contact sites in flat-embedded sections. Analysis of the selected areas in serial ultrathin sections identified 13 cases of either axo-somatic (fig. 3b1, b2, c) or axo-dendritic (fig. 3d1-d6) synapses between GnRH-IR terminals and KP-IR neurones. The GnRH-IR presynaptic profiles contained abundant small round clear vesicles and a few dense core granules that were heavily labelled with silver grains. Each of the 13 synapses detected in the RP3V ( $\mathrm{n}=$ $4)$ and ARC $(n=9)$ was found to be asymmetric.

GnRH Neurones Innervate Kisspeptin Neurones

\section{Discussion}

Previous evidence indicating that GnRH-IR processes establish synaptic connections within the hypothalamus has prompted expansion of the classic concept of $\mathrm{GnRH}$ as merely a hypophysiotrophic factor. Identified targets for such synapses include neurones exhibiting immunoreactivity for ERa in the preoptic area [34] and GnRH neurones themselves [35]. The present findings add KP-IR neurones to this list; the immunofluorescent and electron microscopic evidence shows them to be targeted by GnRHIR processes in both the RP3V and the Arc. Such evidence does not address the question of whether GnRH or a cotransmitter is the active synaptic agent. Nevertheless, there is functional evidence that GnRH per se can regulate the activity of various hypothalamic neuronal systems [3640]. Its actions appear to include the ultrashort feedback regulation of GnRH secretion, as indicated by the singlecell RT-PCR discovery of GnRH-R expression in GnRH neurones [41-43]. In the context of the present findings, it is noteworthy that previous studies involving ligand binding, immunohistochemistry, in situ hybridisation histochemistry or transgenic animals [44-48] have identified GnRH-R-expressing neurones in the rodent RP3V and Arc, sites which contain very few GnRH neurones in those animals; a neurotransmitter phenotype for these GnRH-R-positive cells remains to be determined. 

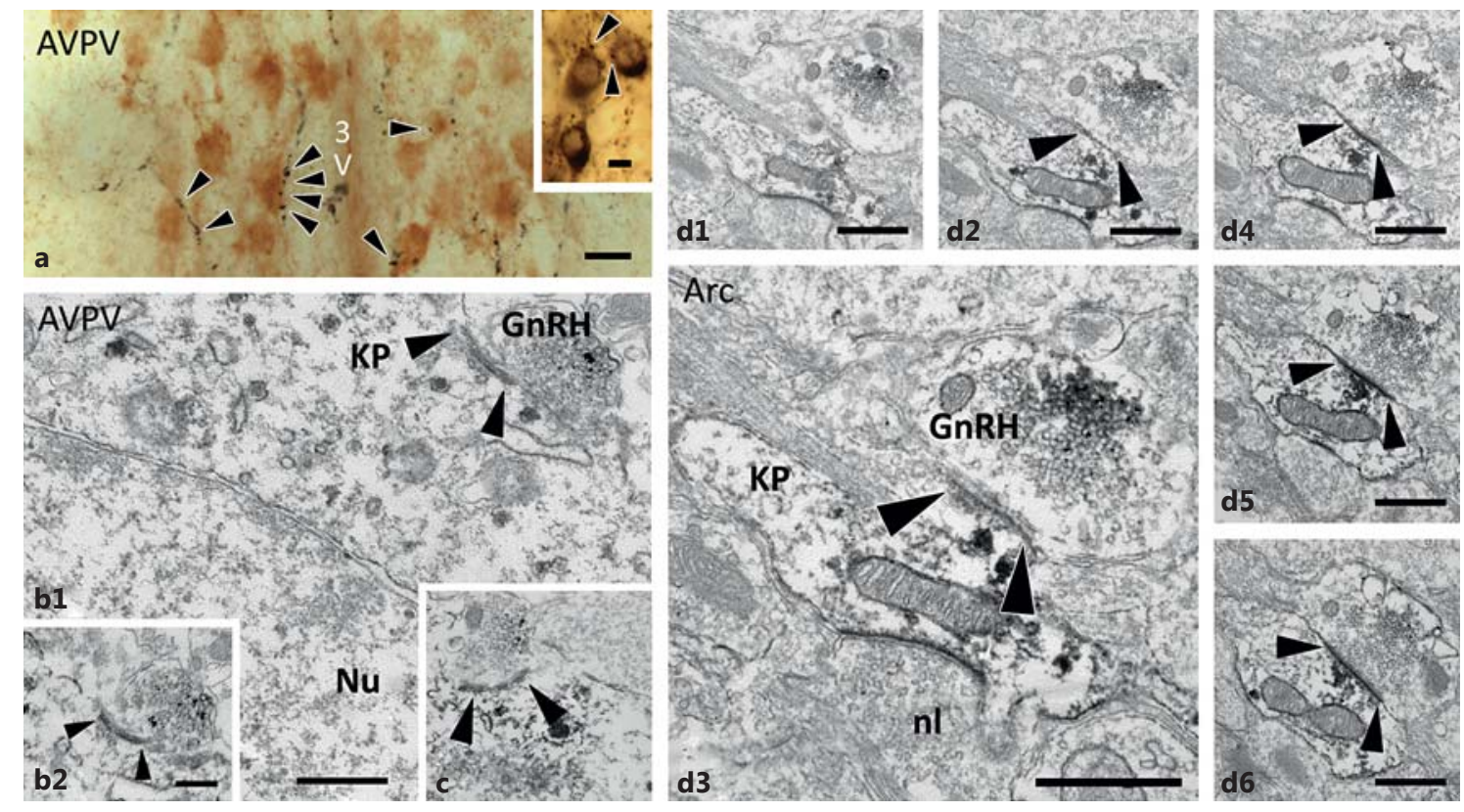

Fig. 3. Double-label immunohistochemical detection of KP-IR neurones and GnRH-IR processes visualised with, respectively, the $\mathrm{DAB}$ brown reaction product (medium electron dense in the electron microscope) and the silver-gold intensified nickel-DAB black reaction product (highly electron dense in the electron microscope). Example of appositions between $\mathrm{GnRH}$-IR varicosities and KP-IR neurones in the AVPV, identified under bright field conditions (arrowheads in a and its inset). At the electron microscopic level, the detected synapses were asymmetric. Arrowheads indicate axo-somatic synapses in the RP3V in b1, b2 (showing the same synapse in adjacent ultrathin sections) and $\mathbf{c}$. A representative axodendritic synapse is shown in the Arc in d1-d6 (showing the same synapse in adjacent ultrathin sections). $\mathrm{Nu}=$ Nucleus; $\mathrm{nl}=$ nonlabelled; $3 \mathrm{~V}=$ third ventricle. Scale bars: $20 \mu \mathrm{m}$ (a), $10 \mu \mathrm{m}$ (inset), 500 nm (b1, d1-d6), 250 nm (b2, c).
In rodents, RP3V KP neurones provide a direct input to GnRH neurones [26, 27, 49]; this is of critical importance in generating the GnRH surge during oestrogen's positive feedback phase [17-21]. The present study provides evidence for connections in the opposite direction. These may provide an indirect route for $\mathrm{GnRH}$ to regulate its own release, thereby supplementing the ultrashort feedback onto GnRH neurones.

The present study also provides evidence for GnRH-IR synaptic input to KP-IR neurones in the Arc. This population of KP neurones has been implicated in the generation of GnRH pulses and in the negative feedback effects of gonadal steroids on the reproductive neuroendocrine axis $[50,51]$. The hypothesis that the Arc KP neurones actively participate in that negative feedback has been challenged by recent findings; they show Arc KP-GFP cells to be almost completely silent in the absence of oestrogen, the proportion of the silent neurones being significantly higher in OVX mice than in those that are ovary-intact [52]. It should be noted that these effects were observed in partially deafferented neurones in coronal slices; further research will be needed to establish the significance of the inputs to Arc KP neurones that are lost in that preparation. Such considerations indicate the importance of elucidating the respective functions of the projections from $\mathrm{GnRH}$ neurones to Arc KP neurones, as shown in the present study, and the previously reported projections in the opposite direction [27].

Given that galanin is a peptide co-transmitter within GnRH neurones [53], it may have a functional role in the synaptic communications identified here. The expression of galanin in rodent $\mathrm{GnRH}$ neurones is sexually differentiated [54-56]. In females, it has been implicated in the regulation of both the surge [57] and pulsatile [58, 59] release of LH. The effect of the co-expressed galanin on $\mathrm{GnRH}$ secretion may derive from an autocrine action on the GnRH/galanin neurones, since both GalR1 and GalR2 mRNAs have been detected in mouse GnRH neurones [41]. A further role for the co-expressed galanin may involve regulation of non-GnRH RP3V and/or Arc neurones that contribute to the control of $\mathrm{GnRH}$ release. This possibility is supported by the presence of galanin recep- 
tor expression in the RP3V (GalR1 and GalR3) and Arc (GalR1) [60-62] and by the capacity of galanin to activate as yet unidentified neurones at both of those sites [63]. Consequently, it will be important to determine whether $\mathrm{KP}$ neurones in the RP3V and/or Arc express GnRH-R and/or GalR1/3. Considering that galanin is also expressed in subsets of RP3V and Arc KP neurones [27, 64], the possibility of its bidirectional involvement in this circuitry merits attention.

The present study identified exclusively asymmetric synapses between GnRH-IR processes and KP-IR neurones in the RP3V and Arc. Although exceptions have been reported, this asymmetric morphology usually reflects excitatory neurotransmission [65]. The presence of the glutamatergic marker, VGLUT2, in most GnRH neurones in rats and mice $[66,67]$ is consistent with putative excitatory glutamatergic transmission from $\mathrm{GnRH}$ neurones at the synapses in question. Furthermore, the abundant small round clear vesicles that were seen in the presynaptic profiles may indicate the presence of glutamate [68]. In contrast, studies on rats and monkeys have found the predominant synaptic morphology between $\mathrm{GnRH}$ IR terminals and GnRH-IR neurones to be symmetric $[35,69,70]$. Whether such relations reflect the previously cited capacity of GnRH to inhibit the reproductive axis [3-6] remains to be determined. Further research will be required to establish whether these two classes of $\mathrm{GnRH}$ IR synapses derive from (1) functionally different subpopulations of GnRH neurones or (2) GnRH neurones that are capable of establishing functionally different synapses on phenotypically distinct target neurones.

It should be recognised that the current study involved colchicine treatment. The extent to which this intervention and the presence or absence of oestrogen may have affected the pre- and post-synaptic sites in the two KP neuronal populations requires detailed investigation. In the present study, GnRH-IR axon varicosities contacted approximately $25 \%$ of the RP3V KP neurones in the oestrogen-treated animals, but they reached approximately
$50 \%$ of the Arc KP neurones in the absence of oestrogen. Previous studies have shown that oestrogen increases not only the incidence of vasopressin-IR afferents to RP3V KP neurones [29], but also the local expression of V1a vasopressin receptors [71]. Presence of this steroid has also been shown to determine the effects of a stressor such as fasting not only on LH release, but also on RP3V KP expression [72]. Consequently, the precise effects of oestrogen on the dynamics of the $\mathrm{GnRH} / \mathrm{KP}$ interactions reported here require further research.

In summary, by demonstrating appositions and asymmetric synapses between GnRH-IR processes and KP-IR neurones, the data presented here provide the first morphological evidence for GnRH-IR innervation of KP neurones in both the RP3V and Arc. The results add a new perspective to the previously reported projections from these KP neuronal populations to GnRH neurones [26, 27]. The projections in the opposite direction may supplement the ultrashort feedback onto GnRH neurones with indirect autoregulatory mechanisms established through the RP3V and Arc KP neurones. Thus, these GnRH-IR terminals may provide substrates for the final common pathway neurones to influence signals from the oestrogen-responsive KP neuronal populations that contribute to the surge and/or pulsatile release of $\mathrm{GnRH}$. The functional significance of the GnRH-IR input to KP neurones and the existence of the regulatory loop we propose based on our new neuroanatomical data will need to be addressed in electrophysiological experiments.

\section{Acknowledgements}

Support contributed by grants from the National Science Foundation of Hungary (OTKA K101326, OTKA K83710, OTKA $\mathrm{K} 100722)$. The research leading to these results has received funding from the European Community's Seventh Framework Programme (FP7/2007-2013) under Grant Agreement 245009. The authors wish to thank Barna László for his excellent technical assistance.

\section{References}

1 King JC, Anthony EL: LHRH neurons and their projections in humans and other mammals: species comparisons. Peptides 1984; 5(suppl 1):195-207.

-2 Ogawa S, Kow LM, Pfaff DW: Effects of lordosis-relevant neuropeptides on midbrain periaqueductal gray neuronal activity in vitro. Peptides 1992;13:965-975.

GnRH Neurones Innervate Kisspeptin

Neurones
3 Naylor AM, Porter DW, Lincoln DW: Inhibitory effect of central LHRH on LH secretion in the ovariectomized ewe. Neuroendocrinology 1989;49:531-536.

$\checkmark 4$ Herman ME, Adams TE: Gonadotropin secretion in ovariectomized ewes: effect of passive immunization against gonadotropin-releasing hormone $(\mathrm{GnRH})$ and infusion of a GnRH agonist and estradiol. Biol Reprod 1990;42:273-280.
5 Bedran de Castro JC, Khorram O, McCann SM: Possible negative ultra-short loop feedback of luteinizing hormone releasing hormone in the ovariectomized rat. Proc Soc Exp Biol Med 1985;179:132-135.

6 DePaolo LV, King RA, Carrillo AJ: In vivo and in vitro examination of an autoregulatory mechanism for luteinizing hormone-releasing hormone. Endocrinology 1987;120:272279 . 
7 Burchanowski BJ, Sternberger LA: Improved visualization of luteinizing hormone-releasing hormone pathways by immunocytochemical staining of thick vibratome sections. J Histochem Cytochem 1980;28:361-363.

-8 Liposits Z, Setalo G, Flerko B: Application of the silver-gold intensified $3,3^{\prime}$-diaminobenzidine chromogen to the light and electron microscopic detection of the luteinizing hormone-releasing hormone system of the rat brain. Neuroscience 1984;13:513-525.

$\checkmark 9$ Herbison AE: Multimodal influence of estrogen upon gonadotropin-releasing hormone neurons. Endocr Rev 1998;19:302-330.

10 Mittelman-Smith MA, Williams H, Krajewski-Hall SJ, Lai J, Ciofi P, McMullen NT, Rance NE: Arcuate kisspeptin/neurokinin B/ dynorphin (KNDy) neurons mediate the estrogen suppression of gonadotropin secretion and body weight. Endocrinology 2012;153: 2800-2812.

$\checkmark 11$ Wintermantel TM, Elzer J, Herbison AE, Fritzemeier KH, Schutz G: Genetic dissection of estrogen receptor signaling in vivo. Ernst Schering Found Symp Proc 2006,1:25-44.

12 Glidewell-Kenney C, Hurley LA, Pfaff L, Weiss J, Levine JE, Jameson JL: Nonclassical estrogen receptor alpha signaling mediates negative feedback in the female mouse reproductive axis. Proc Natl Acad Sci USA 2007; 104:8173-8177.

13 Hrabovszky E, Shughrue PJ, Merchenthaler I, Hajszan T, Carpenter CD, Liposits Z, Petersen SL: Detection of estrogen receptor- $\beta$ messenger ribonucleic acid and ${ }^{125}$ I-estrogenbinding sites in luteinizing hormone-releasing hormone neurons of the rat brain. Endocrinology 2000;141:3506-3509.

-14 Moenter SM, Chu Z: Rapid nongenomic effects of oestradiol on gonadotrophin-releasing hormone neurones. J Neuroendocrinol 2012;24:117-121.

15 Radovick S, Levine JE, Wolfe A: Estrogenic regulation of the GnRH neuron. Front Endocrinol (Lausanne) 2012;3:52.

16 Li XF, Kinsey-Jones JS, Cheng Y, Knox AM, Lin Y, Petrou NA, Roseweir A, Lightman SL, Milligan SR, Millar RP, O’Byrne KT: Kisspeptin signalling in the hypothalamic arcuate nucleus regulates $\mathrm{GnRH}$ pulse generator frequency in the rat. PLoS One 2009;4:e8334.

17 Kinoshita M, Tsukamura H, Adachi S, Matsui $\mathrm{H}$, Uenoyama Y, Iwata K, Yamada S, Inoue K, Ohtaki T, Matsumoto H, Maeda K: Involvement of central metastin in the regulation of preovulatory luteinizing hormone surge and estrous cyclicity in female rats. Endocrinology 2005; 146:4431-4436.

18 Adachi S, Yamada S, Takatsu Y, Matsui H, Kinoshita M, Takase K, Sugiura H, Ohtaki T, Matsumoto $\mathrm{H}$, Uenoyama $\mathrm{Y}$, Tsukamura $\mathrm{H}$, Inoue $\mathrm{K}$, Maeda K: Involvement of anteroventral periventricular metastin/kisspeptin neurons in estrogen positive feedback action on luteinizing hormone release in female rats. J Reprod Dev 2007;53:367-378.
19 Clarkson J, d'Anglemont de Tassigny X, Moreno AS, Colledge WH, Herbison AE: Kisspeptin-GPR54 signaling is essential for preovulatory gonadotropin-releasing hormone neuron activation and the luteinizing hormone surge. J Neurosci 2008;28:86918697.

20 Roseweir AK, Kauffman AS, Smith JT, Guerriero KA, Morgan K, Pielecka-Fortuna J, Pineda R, Gottsch ML, Tena-Sempere M, Moenter SM, Terasawa E, Clarke IJ, Steiner RA, Millar RP: Discovery of potent kisspeptin antagonists delineate physiological mechanisms of gonadotropin regulation. J Neurosci 2009;29:3920-3929.

21 Pineda R, Garcia-Galiano D, Roseweir A, Romero M, Sanchez-Garrido MA, Ruiz-Pino F, Morgan K, Pinilla L, Millar RP, Tena-Sempere M: Critical roles of kisspeptins in female puberty and preovulatory gonadotropin surges as revealed by a novel antagonist. Endocrinology 2010;151:722-730.

22 Clarkson J, d'Anglemont de Tassigny X, Colledge WH, Caraty A, Herbison AE: Distribution of kisspeptin neurones in the adult female mouse brain. J Neuroendocrinol 2009; 21:673-682.

23 Mikkelsen JD, Simonneaux V: The neuroanatomy of the kisspeptin system in the mammalian brain. Peptides 2009;30:26-33 .

24 Smith JT, Cunningham MJ, Rissman EF, Clifton DK, Steiner RA: Regulation of kiss1 gene expression in the brain of the female mouse. Endocrinology 2005;146:3686-3692.

-25 Franceschini I, Lomet D, Cateau M, Delsol G, Tillet Y, Caraty A: Kisspeptin-immunoreactive cells of the ovine preoptic area and arcuate nucleus co-express estrogen receptor- $\alpha$. Neurosci Lett 2006;401:225-230.

26 Clarkson J, Herbison AE: Postnatal development of kisspeptin neurons in mouse hypothalamus; sexual dimorphism and projections to gonadotropin-releasing hormone neurons. Endocrinology 2006;147:5817-5825.

27 Kallo I, Vida B, Deli L, Molnar CS, Hrabovszky E, Caraty A, Ciofi P, Coen CW, Liposits Z: Colocalisation of kisspeptin with galanin or neurokinin B in afferents to mouse GnRH neurones. J Neuroendocrinol 2012;24:464-476.

28 Christian CA, Mobley JL, Moenter SM: Diurnal and estradiol-dependent changes in gonadotropin-releasing hormone neuron firing activity. Proc Natl Acad Sci USA 2005;102: 15682-15687.

29 Vida B, Deli L, Hrabovszky E, Kalamatianos T, Caraty A, Coen CW, Liposits Z, Kallo I: Evidence for suprachiasmatic vasopressin neurones innervating kisspeptin neurones in the rostral periventricular area of the mouse brain: regulation by oestrogen. J Neuroendocrinol 2010;22:1032-1039.
30 Hrabovszky E, Molnar CS, Sipos MT, Vida B, Ciofi P, Borsay BA, Sarkadi L, Herczeg L, Bloom SR, Ghatei MA, Dhillo WS, Kallo I, Liposits Z: Sexual dimorphism of kisspeptin and neurokinin B immunoreactive neurons in the infundibular nucleus of aged men and women. Front Endocrinol (Lausanne) 2011;2:80.

31 Paxinos G, Franklin KBJ: The Mouse Brain in Stereotaxic Coordinates, ed 2. San Diego, Academic Press, 2001.

32 Kallo I, Butler JA, Barkovics-Kallo M, Goubillon ML, Coen CW: Oestrogen receptor $\beta$-immunoreactivity in gonadotropin-releasing hormone-expressing neurones: regulation by oestrogen. J Neuroendocrinol 2001; 13:741-748.

33 Hrabovszky E, Ciofi P, Vida B, Horvath MC, Keller E, Caraty A, Bloom SR, Ghatei MA, Dhillo WS, Liposits Z, Kallo I: The kisspeptin system of the human hypothalamus: sexual dimorphism and relationship with gonadotropin-releasing hormone and neurokinin $\mathrm{B}$ neurons. Eur J Neurosci 2010;31:1984-1998.

34 Langub MC Jr, Maley BE, Watson RE Jr: Ultrastructural evidence for luteinizing hormone-releasing hormone neuronal control of estrogen-responsive neurons in the preoptic area. Endocrinology 1991;128:27-36.

- 35 Leranth C, Segura LM, Palkovits M, MacLusky NJ, Shanabrough M, Naftolin F: The $\mathrm{LH}-\mathrm{RH}$-containing neuronal network in the preoptic area of the rat: demonstration of $\mathrm{LH}$ $\mathrm{RH}$-containing nerve terminals in synaptic contact with LH-RH neurons. Brain Res 1985; 345:332-336

36 McCann SM, Moss RL: Putative neurotransmitters involved in discharging gonadotropin-releasing neurohormones and the action of LH-releasing hormone on the CNS. Life Sci 1975;16:833-852.

37 Renaud LP, Martin JB, Brazeau P: Hypothalamic releasing factors: physiological evidence for a regulatory action on central neurons and pathways for their distribution in brain. Pharmacol Biochem Behav 1976;5: 171-178.

38 Rothfeld JM, Carstens E, Gross DS: Neuronal responsiveness to gonadotropin-releasing hormone and its correlation with sexual receptivity in the rat. Peptides 1985;6:603-608.

39 Pan JT, Kow LM, Pfaff DW: Modulatory actions of luteinizing hormone-releasing hormone on electrical activity of preoptic neurons in brain slices. Neuroscience 1988;27: 623-628.

40 Chen P, Moenter SM: Gabaergic transmission to gonadotropin-releasing hormone $(\mathrm{GnRH})$ neurons is regulated by GnRH in a concentration-dependent manner engaging multiple signaling pathways. J Neurosci 2009;29:98099818.

-41 Todman MG, Han SK, Herbison AE: Profiling neurotransmitter receptor expression in mouse gonadotropin-releasing hormone neurons using green fluorescent protein-promoter transgenics and microarrays. Neuroscience 2005;132:703-712. 
-42 Xu C, Roepke TA, Zhang C, Ronnekleiv OK, Kelly MJ: Gonadotropin-releasing hormone $(\mathrm{GnRH})$ activates the M-current in $\mathrm{GnRH}$ neurons: an autoregulatory negative feedback mechanism? Endocrinology 2008; 149:24592466.

43 Xu C, Xu XZ, Nunemaker CS, Moenter SM: Dose-dependent switch in response of gonadotropin-releasing hormone ( $\mathrm{GnRH}$ ) neurons to GnRH mediated through the type I GnRH receptor. Endocrinology 2004;145:728-735.

44 Badr M, Pelletier G: Characterization and autoradiographic localization of LHRH receptors in the rat brain. Synapse 1987;1:567-571.

45 Jennes L, Dalati B, Conn PM: Distribution of gonadrotropin-releasing hormone agonistbinding sites in the rat central nervous system. Brain Res 1988;452:156-164.

-46 Roth C, Schricker M, Lakomek M, Strege A, Heiden I, Luft H, Munzel U, Wuttke W, Jarry $\mathrm{H}$ : Autoregulation of the gonadotropin-releasing hormone $(\mathrm{GnRH})$ system during puberty: effects of antagonistic versus agonistic $\mathrm{GnRH}$ analogs in a female rat model. J Endocrinol 2001;169:361-371.

-47 Seong JY, Kang SS, Kam K, Han YG, Kwon HB, Ryu K, Kim K: Differential regulation of gonadotropin-releasing hormone (GnRH) receptor expression in the posterior mediobasal hypothalamus by steroid hormones: implication of GnRH neuronal activity. Brain Res Mol Brain Res 1998;53:226-235.

-48 Wen S, Gotze IN, Mai O, Schauer C, LeindersZufall T, Boehm U: Genetic identification of GnRH receptor neurons: a new model for studying neural circuits underlying reproductive physiology in the mouse brain. Endocrinology 2011;152:1515-1526.

49 Pielecka-Fortuna J, Chu Z, Moenter SM: Kisspeptin acts directly and indirectly to increase gonadotropin-releasing hormone neuron activity and its effects are modulated by estradiol. Endocrinology 2008;149:1979-1986.

50 Navarro VM, Gottsch ML, Chavkin C, Okamura H, Clifton DK, Steiner RA: Regulation of gonadotropin-releasing hormone secretion by kisspeptin/dynorphin/neurokinin B neurons in the arcuate nucleus of the mouse. J Neurosci 2009;29:11859-11866.

51 Smith MA, Williams H, Krajewski SJ, McMullen NT, Rance NE: Arcuate NK3 receptor-expressing KNDy neurons are essential for estrogen modulation of $\mathrm{LH}$ secretion and body weight in the female rat. Washington, Society for Neuroscience, 2011.
2 De Croft S, Piet R, Mayer C, Mai O, Boehm U, Herbison AE: Spontaneous kisspeptin neuron firing in the adult mouse reveals marked sex and brain region differences but no support for a direct role in negative feedback. Endocrinology 2012;153:5384-5393.

53 Coen CW, Montagnese C, Opacka-Juffry J: Coexistence of gonadotrophin-releasing hormone and galanin: immunohistochemical and functional studies. J Neuroendocrinol 1990;2:107-111.

54 Finn PD, McFall TB, Clifton DK, Steiner RA: Sexual differentiation of galanin gene expression in gonadotropin-releasing hormone neurons. Endocrinology 1996; 137:47674772.

55 Liposits Z, Reid JJ, Negro-Vilar A, Merchenthaler I: Sexual dimorphism in co-packaging of luteinizing hormone-releasing hormone and galanin into neurosecretory vesicles of hypophysiotrophic neurons: estrogen dependency. Endocrinology 1995;136:1987-1992.

56 Merchenthaler I, Lopez FJ, Lennard DE, Negro-Vilar A: Sexual differences in the distribution of neurons coexpressing galanin and luteinizing hormone-releasing hormone in the rat brain. Endocrinology 1991;129:19771986.

57 Lopez FJ, Meade EH Jr, Negro-Vilar A: Endogenous galanin modulates the gonadotropin and prolactin proestrous surges in the rat. Endocrinology 1993;132:795-800.

58 Lopez FJ, Merchenthaler IJ, Moretto M, Negro-Vilar A: Modulating mechanisms of neuroendocrine cell activity: the LHRH pulse generator. Cell Mol Neurobiol 1998;18:125146.

59 Xu B, Pu S, Kalra PS, Hyde JF, Crowley WR, Kalra SP: An interactive physiological role of neuropeptide $\mathrm{Y}$ and galanin in pulsatile pituitary luteinizing hormone secretion. Endocrinology 1996;137:5297-5302.

-60 Hohmann JG, Jureus A, Teklemichael DN, Matsumoto AM, Clifton DK, Steiner RA: Distribution and regulation of galanin receptor 1 messenger RNA in the forebrain of wild-type and galanin-transgenic mice. Neuroscience 2003;117:105-117.

61 Mennicken F, Hoffert C, Pelletier M, Ahmad S, O'Donnell D: Restricted distribution of galanin receptor-3 (GALR3) mRNA in the adult rat central nervous system. J Chem Neuroanat 2002;24:257-268.

62 Waters SM, Krause JE: Distribution of galanin-1, -2 and -3 receptor messenger RNAs in central and peripheral rat tissues. Neuroscience 2000;95:265-271.
63 Fraley GS, Shimada I, Baumgartner JW, Clifton DK, Steiner RA: Differential patterns of fos induction in the hypothalamus of the rat following central injections of galanin-like peptide and galanin. Endocrinology 2003; 144:1143-1146.

64 Porteous R, Petersen SL, Yeo SH, Bhattarai JP, Ciofi P, D’Anglemont de Tassigny X, Colledge WH, Caraty A, Herbison AE: Kisspeptin neurons co-express met-enkephalin and galanin in the rostral periventricular region of the female mouse hypothalamus. J Comp Neurol 2011;519:3456-3469.

65 Klemann CJ, Roubos EW: The gray area between synapse structure and function-gray's synapse types I and II revisited. Synapse 2011; 65:1222-1230.

66 Hrabovszky E, Turi GF, Kallo I, Liposits Z: Expression of vesicular glutamate transporter-2 in gonadotropin-releasing hormone neurons of the adult male rat. Endocrinology 2004;145:4018-4021.

67 Wu M, Dumalska I, Morozova E, van den Pol AN, Alreja M: Gonadotropin inhibitory hormone inhibits basal forebrain VGLUT2-gonadotropin-releasing hormone neurons via a direct postsynaptic mechanism. J Physiol 2009;587:1401-1411.

68 El Mestikawy S, Wallen-Mackenzie A, Fortin GM, Descarries L, Trudeau LE: From glutamate co-release to vesicular synergy: vesicular glutamate transporters. Nat Rev Neurosci 2011;12:204-216.

69 Chen WP, Witkin JW, Silverman AJ: Betaendorphin and gonadotropin-releasing hormone synaptic input to gonadotropin-releasing hormone neurosecretory cells in the male rat. J Comp Neurol 1989;286:85-95.

70 Thind KK, Goldsmith PC: Infundibular gonadotropin-releasing hormone neurons are inhibited by direct opioid and autoregulatory synapses in juvenile monkeys. Neuroendocrinology 1988;47:203-216.

71 Kalamatianos T, Kallo I, Goubillon ML, Coen CW: Cellular expression of V1a vasopressin receptor MRNA in the female rat preoptic area: effects of oestrogen. J Neuroendocrinol 2004;16:525-533.

72 Kalamatianos T, Grimshaw SE, Poorun R, Hahn JD, Coen CW: Fasting reduces kiss-1 expression in the anteroventral periventricular nucleus (AVPV): effects of fasting on the expression of kiss-1 and neuropeptide $\mathrm{Y}$ in the AVPV or arcuate nucleus of female rats. J Neuroendocrinol 2008;20:1089-1097. 